\title{
SHARE OF STRENGTH PARAMETERS OF BENCH PRESS AND BARBELL BENCH PULL ON A HORIZONTAL BENCH IN SPORTS PERFORMANCE IN KAYAK DISCIPLINES
}

\author{
Jaroslav Brodáni ${ }^{1 \mathrm{ABCD}}$, Natália Dvořáčková ${ }^{\mathrm{ABCD}}$, \\ Monika Czaková ${ }^{3 \mathrm{ABCD}}$, Zdenek Malík ${ }^{4 \mathrm{~B}}$, Peter Lopata ${ }^{5 \mathrm{~B}}$ \\ ${ }^{1,2,3,4}$ Constantine the Philosopher University, Nitra \\ ${ }^{5}$ Slovak National Sports Center, Bratislava \\ Authors' Contribution: A - Study design; B - Data collection; C - Statistical analysis; D - Manuscript Preparation; E - Funds Collection \\ Corresponding Author: Monika Czaková, E-mail: monika.czakova@ukf.sk \\ Accepted for Publication: March 20, 2021 \\ Published: March 25, 2021
}

DOI: 10.17309/tmfv.2021.1.12

\begin{abstract}
The objective of the study was to deal with the ratio of the parameters of maximum muscle power and power endurance and explain their contribution to the sports performance in kayak disciplines of Slovakia National Team members.

Material and methods. Strength parameters were monitored by Tendo Power Analyser in the barbell bench press and pull on a horizontal bench. A diagnostic series of maximum power and effective repetition test for power endurance was performed at both, barbell bench press and bench pull exercises. Determining the factors limiting sports performance in kayak disciplines 200 meters, 500 meters, 1,000 meters, 5,000 meters, and marathon 21,500 meters, the evaluation of dependence between all power variables were used. The stepwise regression was used to reduce the indicators.

Results. It was found out that in kayak sprint disciplines (200 meters, 500 meters) the sports performance in the kayak is influenced by the barbell bench pull more than bench press on the horizontal bench when speaking about the strength parameters. In the middle-distance disciplines (1,000 meters), the ratio of strength parameters is balanced. As the length of kayak disciplines increases (5,000 meters and 21,500 meters), the ratio of strength parameters has changed in favor of the barbell bench press.

From the parameters of maximum muscle performance and muscle endurance measured in the barbell bench press and pull on a horizontal bench, the average power of power endurance was demonstrated to explain the sports performance in kayak disciplines.

Conclusion. From the parameters of maximum power and power endurance in the bench press and bench pull in all kayak disciplines, the parameter of average power in power endurance was proved to explain sports performance. Knowledge of these factors will allow optimizing the content of sports training of kayakers, the process of developing their strength skills, and their transformation process into a structure of sports performance and kayaking paddling technique. Keywords: sports performance, kayak disciplines, stepwise regression, National Sports Center
\end{abstract}

\section{Introduction}

Sports disciplines in kayaking and canoeing are gaining more and more popularity (Akca \& Muniruglu, 2008). Canoe Sprint is a traditional Olympic sport (Bielik et al., 2019) that belongs to one of the most successful sports in Slovakia and the Czech Republic, as evidenced by many gold, silver, and bronze medals from international competitions, Olympic Games, World Championships and Europe (McKean \& Burkett, 2014). It is a water sport performed on calm stagnant or slightly flowing waters, whether they are natural or artificial (Plagenhoef, 1979). The goal is to overcome with the boat the distance in the shortest possible time. Races can

(C) Brod'áni, J., Dvořáčková, N., Monika Czaková, M., Zdenek Malík, Z., Lopata, P., 2021. be on two types of boats, first is canoe which is divided to $\mathrm{C} 1, \mathrm{C} 2, \mathrm{C} 4$ (depending on the number of competitors on the boat), and the second is the kayak which is divided to $\mathrm{K} 1, \mathrm{~K} 2$, K4 (Schmidt, 1992; Doktor, 2001; Barton, 2002). In a canoe, the paddler kneels and uses a single-bladed paddle to propel the boat forward and in the kayak, the paddler is seated and uses a double-bladed paddle pulling the blade through the water on alternate sides to move forward (Baker, Rath, Sanders, Kelly, 1999; Sendelbeck \& Schmid, 2016). Sprint canoe is the strength-endurance type of sport; however, this does not mean that it depends only on the strength and endurance abilities of the individual which fall into conditioning factors affecting sports performance (Lopata, 2014). In modern elite sports nowadays identification of the best training methods 

and Barbell Bench Pull on a Horizontal Benchin Sports Performance in Kayak Disciplines

is used, which is useful for improving strategies during competitions. Such a strategy requires accurate measurements of biomechanical and physiological parameters affecting sports performance (Kendal, Sanders, 1992). Due to constant paddling, kayaking is considered demanding muscular activity consisting of cyclic and acyclic uneven movements (Stecenko, 1982, Vieira et al., 2015). Paddling requires proper technique and coordination of movement and muscles so that movement is economical and only the muscles necessary during paddling are involved (Bauer, 1988; Gagin, 1981). When paddling, the strength of the upper limbs is used, but the lower part of the body also contributes. Paddling itself can be further characterized as forward-pressure movements and backward-pulling movements (Borkovcová, 2005; Janura, Kratochvíl, Lehnert \& Veverka, 2005). In kayaking, we distinguish disciplines of $200 \mathrm{~m}, 500 \mathrm{~m}, 1000 \mathrm{~m}, 5000 \mathrm{~m}$, and marathon 21500 m (Grigorijev, Krasnopecev, 1972). Seating and support of the boat differ according to the discipline.

The objective of the study was to find the rate of the proportion of strength parameters measured in bench press and bench pull on the horizontal bench on explaining the sports performance in the kayak disciplines at 200 meters, 500 meters, 1000 meters, 5000 meters, and in the marathon 21500 meters. It was assumed, based on the previous studies, that the indicator of the average power of power endurance in the bench press will contribute the most to the explanation of sports performance in the kayak disciplines.

\section{Material and methods}

\section{Study participants}

The research sample consisted of representatives of the Slovak republic in kayaking $\mathrm{N}=17$, with average age $\mathrm{M}=$ 16.82 years $\mathrm{SD}=0.89$. The average body height of sample was $\mathrm{M}=175.44 \mathrm{~cm}, \mathrm{SD}=23.19$ and average body weight $\mathrm{M}=$ $84.62 \mathrm{~kg}, \mathrm{SD}=27.57 \mathrm{~kg}$.

\section{Study organization}

The level of physical development, strength parameters, and sports performance is characterized by mean (M), standard deviation (SD), minimum (Min), maximum (Max) in Tables 1 and 2. The measurement of strength parameters took place in the Slovak National Sports Center. The best results in the kayak disciplines of 2019 were obtained from the documents of the Slovak Canoe Association.

Bench press and bench pull strength parameters were measured by the Tendo power analyzer. Tendo power analyzer measures average power and velocity, partial average power, peak power, velocity and force, eccentric average ve-
Table 2 Sports performance of the monitored group in kayak disciplines

\begin{tabular}{lcccc}
\hline $\begin{array}{c}\text { Kayak } \\
\text { disciplines }\end{array}$ & M & SD & Max & Min \\
\hline $200 \mathrm{~m}[\mathrm{~s}]$ & 41.12 & 1.74 & 43.87 & 38.16 \\
$500 \mathrm{~m}[\mathrm{~min}]$ & $1: 55.28$ & $0: 03.57$ & $2: 01.84$ & $1: 48.96$ \\
$1000 \mathrm{~m}[\mathrm{~min}]$ & $4: 04.93$ & $0: 04.88$ & $4: 12.55$ & $3: 58.00$ \\
$5000 \mathrm{~m}[\mathrm{~min}]$ & $23: 04.15$ & $0: 58.52$ & $25: 39.30$ & $21: 50.03$ \\
$21500 \mathrm{~m}[\mathrm{~h}]$ & $1: 47: 28$ & $0: 05: 19$ & $1: 55: 01$ & $1: 40: 48$ \\
\hline
\end{tabular}

locity, and rest time between reps or sets. In bench press and bench pull were performed diagnostic series of maximum power (weight of the barbell and average power) and test of effective repetitions for the power endurance (weight of the barbell, average power, number of repetitions). The weight of the barbell was the same in the bench press and bench pull.

\section{Statistical analysis}

When defining the limiting factors of sports performance in kayak discipline, the base is on the evaluation of dependence between every strength parameter. Step regression analysis was used for the reduction of indicators and the elimination of multicollinearity. This technique has used the method Backward, which is characterized by the gradual separation of variables from the total set in the regression function. These are back-tested to see if they statistically affect the quality of the regression model. Dependency (Pearson correlation coefficient $r$ ) and share $\left(\beta \operatorname{eta}^{\star} r\right)$ of individual factors were determined by the correlation and regression analysis. From the regression parameters, we present the determinant of multiple correlation (R2) and the significance of the model (F). Effect size is measured by Cohen's $\mathrm{d}$ and f2 (Cohen, 1998). Statistical significance is assessed on two significance levels $\mathrm{p}<0.05$ and $\mathrm{p}<0.01$ and effect size on $0.02=$ small; 0.15 = medium; 0.35 = large effect. Empirical data were processed and evaluated in MS Excel and SPSS.

\section{Results}

When verifying the hypothesis, it was assumed that the indicator of the average power on the bench will contribute most to the explanation of sports performance in kayak discipline on 200 meters, 500 meters, 1000 meters 5000 meters and in marathon 21500 meters. To verify this hypothesis, technique of correlation, regression, and step analysis were used.

By the correlation analysis between parameters of strength in bench press and bench pull on the horizontal bench with the sports performance, the interactions were proven to a minimal extent. The strength parameters of the

Table 1 Comparison of the level of strength parameters in bench press and bench pull on the horizontal bench

\begin{tabular}{|c|c|c|c|c|c|c|c|c|}
\hline \multirow{2}{*}{\multicolumn{2}{|c|}{ Tendo Power Analyzer }} & \multicolumn{2}{|c|}{ Bench press } & \multicolumn{2}{|c|}{ Bench pull } & \multirow{2}{*}{ t-test } & \multirow{2}{*}{$\mathbf{p}$} & \multirow{2}{*}{ d } \\
\hline & & $\bar{M}$ & SD & $\mathbf{M}$ & SD & & & \\
\hline \multirow{2}{*}{$\begin{array}{l}\text { Maximum } \\
\text { power }\end{array}$} & Barbell weight [kg] & 58.235 & 5.847 & 61.471 & 6.063 & 2.184 & 0.044 & 0.543 \\
\hline & Average power [W] & 538.647 & 55.913 & 654.118 & 76.587 & 9.608 & 0.000 & 1.722 \\
\hline \multirow{3}{*}{$\begin{array}{l}\text { Power } \\
\text { endurance }\end{array}$} & Barbell weight $[\mathrm{kg}]$ & 58.235 & 5.847 & 61.176 & 6.002 & 2.184 & 0.044 & 0.543 \\
\hline & Average power [W] & 486.294 & 39.352 & 571.873 & 57.952 & 7.491 & 0.000 & 1.728 \\
\hline & Repetitions [n] & 8.176 & 2.378 & 6.941 & 3.132 & 1.558 & 0.139 & 0.444 \\
\hline
\end{tabular}


Table 3. Correlations of strength parameters in bench press and bench pull on horizontal bench with the sports performance in kayak disciplines $\left(\mathrm{p}<0.05^{\star} ; \mathrm{p}<0.01^{\star *}\right)$

\begin{tabular}{|c|c|c|c|c|c|c|c|}
\hline \multicolumn{3}{|c|}{ Indicator } & \multirow{2}{*}{$\frac{200 \mathrm{~m}}{-0.166}$} & \multirow{2}{*}{$\begin{array}{c}\mathbf{5 0 0} \mathbf{~ m} \\
-0.345\end{array}$} & \multirow{2}{*}{$\begin{array}{r}1000 \mathbf{m} \\
-0.200\end{array}$} & \multirow{2}{*}{$\begin{array}{r}5000 \mathbf{m} \\
-0.011\end{array}$} & \multirow{2}{*}{$\frac{21500 \mathbf{m}}{-0.374}$} \\
\hline \multirow{5}{*}{ Bench press } & \multirow{2}{*}{ Maximum power } & Barbell weight $[\mathrm{kg}]$ & & & & & \\
\hline & & Average power [W] & -0.141 & -0.250 & -0.043 & 0.143 & -0.351 \\
\hline & \multirow{3}{*}{ Power endurance } & Barbell weight $[\mathrm{kg}]$ & -0.166 & -0.345 & -0.200 & -0.011 & -0.374 \\
\hline & & Average power [W] & -0.301 & -0.401 & -0.160 & 0.255 & -0.218 \\
\hline & & Repetitions [n] & -0.220 & -0.021 & -0.223 & 0.110 & -0.117 \\
\hline \multirow{5}{*}{ Bench pull } & \multirow{2}{*}{ Maximum power } & Barbell weight $[\mathrm{kg}]$ & -0.034 & -0.188 & 0.142 & -0.029 & -0.023 \\
\hline & & Average power [W] & -0.211 & -0.186 & -0.059 & -0.038 & -0.234 \\
\hline & \multirow{3}{*}{ Power endurance } & Barbell weight $[\mathrm{kg}]$ & -0.106 & -0.230 & 0.118 & -0.164 & -0.067 \\
\hline & & Average power $[\mathrm{W}]$ & $-0.505^{\star}$ & $-0.493^{\star}$ & -0.196 & -0.059 & -0.231 \\
\hline & & Repetitions [n] & 0.229 & 0.313 & -0.212 & 0.160 & -0.022 \\
\hline
\end{tabular}

bench press did not show any statistically significant relations with sports performance in ani kayak discipline. From the bench pull parameters on the horizontal bench were statistically significant interactions of the average power of power endurance $(\mathrm{W})$ to the sprint disciplines on $200 \mathrm{~m} \mathrm{r}(17)=$ $-0.505 ; \mathrm{p}<0.05$ and to $500 \mathrm{~m} \mathrm{r}(17)=-0.493, \mathrm{p}<0.05$. Other remaining interactions between the strength parameters and sports performance were not statistically significant (Tab. 3).

Another technique used to determine the proportions of factors limiting sports performance was the multiple regression analysis of all strength parameters individually in bench press and bench pull on the horizontal bench. The multiples of the $\beta$ eta correlation coefficients and the correlation coefficients " $r$ " were calculated the partial shares (Tab. 4) to the sports performance. The highest contribution to the explanation of sports performance in the discipline of kayaking at 200 meters has the bench pull (38\%) before the bench press (10.1\%). From the parameters of power endurance in bench pull are important parameters of the average power $25.3 \%$, the number of repetitions $7.7 \%$, and maximum power $5.2 \%$.

Same in 500 meters kayaking, the bench pull (30.9\%) is over that bench press (25.0\%). From the bench pull parameters, it is represented by power endurance (19.4\%) and by numbers of repetitions (11.1\%). In the bench press, key parameters are the weight of the barbell (11.5\%), maximum power $(6.4 \%)$, and average power $(6.8 \%)$. The share of strength parameters in 1000 meters kayaking is similar (12.0\% and $11.8 \%)$. In both cases "press vs. pull" are key parameters of the weight of the barbell (7.1\% and 5.0\%), num- bers of repetitions (3.9\% and 3.3\%), and average power in the power endurance (1.1\% and 3.1\%). As the length of the kayak disciplines increases, the proportion of strength parameters changes in favor of the strength parameters at the bench press over the bench pull (5000 meters: $17.9 \%<>5.5 \% ; 21500 \mathrm{~m}$ : $36.6 \%<>1.3 \%)$. In the discipline of 5000 meters kayaking, key parameters are the average power endurance $(11.3 \%)$ and maximum power performance (5.9\%). In marathon discipline (21500 meters) are important parameters of barbell weight $(17.6 \%)$ and average maximum power (14.5\%). It shows that in the sprint disciplines of kayaking (200 meters and 500 meters) the highest share on the sports performance has the strength parameters in bench pull before the bench press on the horizontal bench. In the medium distances (1000 meters) is the share of bench press and bench pull parameters equal. As the length of the kayak disciplines increases (5000 meters and 21500 meters), the proportion of strength parameters changes in favor of parameters of strength in the bench press.

When identification of limiting factors of sports performance in kayak disciplines, the reduction of indicators of all strength parameters individually in bench press and bench pull on a horizontal bench are used. For the reduction of indicators, the stepwise regression analysis was used. Mostly in all kayak disciplines, the parameter of average power in power endurance (Tab. 5) in the bench press and bench pull has the greatest information power.

In the complex reduction of strength parameters in the bench press and bench pull, the previous findings have been confirmed. In sprint disciplines, the parameters of bench pull

Table 4. Partial shares of strength parameters in bench press and bench pull on horizontal bench on the sports performance in kayak disciplines (ßetar)

\begin{tabular}{llccccc}
\hline \multirow{2}{*}{ Indicator } & \multicolumn{2}{c}{ Maximum power } & \multicolumn{3}{c}{ Power endurance } \\
\cline { 3 - 7 } & & Barbell weight[kg] & Average power [W] & Average power[W] & Repetitions [n] & $\mathbf{R}^{2}$ \\
\hline \multirow{2}{*}{$200 \mathrm{~m}$} & Bench Press & 0.033 & -0.007 & 0.002 & 0.072 & 0.101 \\
& Bench Pull & -0.002 & 0.052 & 0.253 & 0.003 & 0.308 \\
\hline \multirow{2}{*}{$500 \mathrm{~m}$} & Bench Press & 0.115 & 0.064 & 0.068 & 0.111 & 0.250 \\
& Bench Pull & 0.005 & -0.002 & 0.194 & 0.039 & 0.033 \\
\hline \multirow{2}{*}{$1000 \mathrm{~m}$} & Bench Press & 0.071 & 0.000 & 0.011 & 0.007 & 0.120 \\
& Bench Pull & 0.050 & 0.004 & 0.113 & 0.022 \\
\hline \multirow{2}{*}{$5000 \mathrm{~m}$} & Bench Press & 0.000 & 0.059 & 0.019 & 0.179 \\
& Bench Pull & 0.001 & 0.013 & 0.027 & 0.014 & 0.055 \\
\hline \multirow{2}{*}{$21500 \mathrm{~m}$} & Bench Press & 0.176 & 0.145 & 0.036 & 0.000 \\
& Bench Pull & -0.004 & -0.019 & & 0.013 \\
\hline
\end{tabular}


Brod'áni, J., Dvořáčková, N., Monika Czaková, M., Zdenek Malík, Z., \& Lopata, P. (2021). Share of Strength Parameters of Bench Press and Barbell Bench Pull on a Horizontal Benchin Sports Performance in Kayak Disciplines

Table 5. Step regression of strength parameters in bench press and bench pull to sports performance in kayak disciplines $\left(\beta \operatorname{eta}^{*} \mathrm{r}\right)$

\begin{tabular}{|c|c|c|c|c|c|c|c|c|c|c|}
\hline \multirow{2}{*}{\multicolumn{2}{|c|}{ Indicator }} & \multicolumn{2}{|c|}{ Maximum power } & \multicolumn{3}{|c|}{ Power endurance } & \multirow[b]{2}{*}{ F } & \multirow[b]{2}{*}{ sig } & \multirow[b]{2}{*}{$\mathbf{R}^{2}$} & \multirow[b]{2}{*}{$\mathbf{f}^{2}$} \\
\hline & & $\begin{array}{l}\text { Barbell } \\
\text { weigth }\end{array}$ & $\begin{array}{c}\text { Average } \\
\text { power }\end{array}$ & $\begin{array}{l}\text { Barbell } \\
\text { weight }\end{array}$ & $\begin{array}{c}\text { Average } \\
\text { power }\end{array}$ & Repetitions & & & & \\
\hline \multirow{2}{*}{$200 \mathrm{~m}$} & Bench Press & - & - & - & 0.090 & - & 1.499 & 0.240 & 0.091 & 0.100 \\
\hline & Bench Pull & -0.028 & - & - & 0.405 & 0.141 & 4.792 & 0.018 & 0.065 & 0.070 \\
\hline \multirow{2}{*}{$500 \mathrm{~m}$} & Bench Press & - & - & - & 0.209 & - & 2.871 & 0.111 & 0.161 & 0.191 \\
\hline & Bench Pull & - & - & - & -0.154 & - & 4.827 & 0.044 & 0.287 & 0.402 \\
\hline \multirow{2}{*}{$1000 \mathrm{~m}$} & Bench Press & - & - & - & 0.065 & - & 0.785 & 0.390 & 0.050 & 0.052 \\
\hline & Bench Pull & - & - & - & 0.039 & - & 0.601 & 0.450 & 0.039 & 0.040 \\
\hline \multirow{2}{*}{$5000 \mathrm{~m}$} & Bench Press & - & - & - & 0.065 & - & 1.043 & 0.323 & 0.065 & 0.070 \\
\hline & Bench Pull & -0.116 & -0.017 & 0.712 & - & - & 6.274 & 0.007 & 0.598 & 1.486 \\
\hline \multirow{2}{*}{$21500 \mathrm{~m}$} & Bench Press & - & - & 0.147 & - & - & 2.444 & 0.139 & 0.140 & 0.163 \\
\hline & Bench Pull & - & - & - & 0.053 & - & 0.843 & 0.373 & 0.053 & 0.056 \\
\hline
\end{tabular}

Table 6. Step regression of all strength parameters to sports performance in kayak disciplines ( $\beta e \mathrm{eta}^{\star} \mathrm{r}$ )

\begin{tabular}{|c|c|c|c|c|c|c|c|c|c|c|}
\hline \multirow{2}{*}{\multicolumn{2}{|c|}{ Indicator }} & \multicolumn{2}{|c|}{ Maximum power } & \multicolumn{3}{|c|}{ Power endurance } & \multirow[b]{2}{*}{ F } & \multirow[b]{2}{*}{ Sig } & \multirow[b]{2}{*}{$\mathbf{R}^{2}$} & \multirow[b]{2}{*}{$\mathbf{f}^{2}$} \\
\hline & & $\begin{array}{l}\text { Barbell } \\
\text { weight }\end{array}$ & $\begin{array}{l}\text { Average } \\
\text { power }\end{array}$ & $\begin{array}{l}\text { Barbell } \\
\text { weigth }\end{array}$ & $\begin{array}{l}\text { Average } \\
\text { power }\end{array}$ & Repetitions & & & & \\
\hline $200 \mathrm{~m}$ & Bench Pull & - & - & -0.020 & 0.405 & 0.141 & 4.789 & 0.018 & 0.525 & 1.105 \\
\hline $500 \mathrm{~m}$ & Bench Pull & - & - & - & 0.243 & - & 4.823 & 0.044 & 0.243 & 0.322 \\
\hline $1000 \mathrm{~m}$ & Bench Pull & - & - & - & - & 0.045 & 0.707 & 0.414 & 0.045 & 0.047 \\
\hline $5000 \mathrm{~m}$ & Bench Press & - & - & - & 0.065 & - & 1.043 & 0.323 & 0.065 & 0.070 \\
\hline $21500 \mathrm{~m}$ & Bench Press & 0.140 & - & - & - & - & 2.444 & 0.139 & 0.140 & 0.163 \\
\hline
\end{tabular}

are statistically significant. In the endurance disciplines, the parameters of the bench press proved to be statistically significant.

In 200 meters, the greatest share on the sports performance has the average power $(40.5 \%)$ and the numbers of repetitions in the power endurance (14.1\%). A high share of average power in power endurance $(24.3 \%)$ is recorded in 500 meters kayaking discipline. The significance of parameters to the sports performance was confirmed in both cases statistically $(p<0.05)$ with the effect size $f 2>0.3$. In endurance kayak disciplines, the results are ambiguous according to their statistical significance. A factor of effective repetitions in power endurance in bench pull (4.5\%) was measured in 1000 meters kayaking. The bench press is the limiting factor in the endurance kayak disciplines in 5000 meters (average power in power endurance 6.5\%) and in 21500 meters (barbell weight 14.0\%).

\section{Discussion}

This study aimed to compare the strength parameters measured in bench press and bench pull in the horizontal bench on the explanation of the sports performance in kayak disciplines in 200 meters, 500 meters, 1000 meters, 5000 meters, and in marathon 21500 meters (Endicott, 1995; Potočný, 1985). Data were recorded through the Tendo power analyzer. This study shows that the parameter of average power in power endurance (Strnadová, 2004) in the bench press and bench pull, has a great impact on the sports performance in kayak disciplines. Interactions of sports performance and strength parameters in the bench press did not prove to be statistically significant. Interactions of sports performance and strength parameters in bench pull were significant in the average power of power endurance in 200 meters and 500 meters. Sports performance partial shares in kayak disciplines determine limit- ing factors. In the discipline of 200 meters, have the highest share on the sports performance the bench pull parameters (power endurance in average power, numbers of repetitions, and maximum power). Similarly, in the 500 meters discipline the bench pull was a key determinant in parameters of power endurance and numbers of repetitions. In the bench press, the important determinants were the barbell weight, maximum power, and average power (Bílý et al., 2000). In the 1000 meters discipline, the parameters of barbell weight, numbers of repetitions, and average power in power endurance prevailed. The share of strength parameters in the bench press and bench pull is equal (Joachimsthaler, 1967; Rodano, Squadrone, Sacchi, \& Marzegan, 2001). The average power endurance and maximum power in the bench press were key determinants in 5000 meters long discipline. In kayaking marathon (21500 meters) prevailed parameters of barbell weight and average maximum power measured in the bench press (Janura, Kubu, Kratochvíl \& Stromšík, 2000). According to continuous measurements, performance in the kayak discipline is greatly influenced by the technique (Bauer, 1988; Fučíková, 2003). According to Janura et al. (2000), an effective technique can be described as a symmetrical range of movement of both hands, minimal torso movement in the anteroposterior direction, and greater arm rotation, which author calls mechanical skill. Doktor (2001) and Schmidt analyze in their work the paddling techniques. Strnadová (2004) discussed the importance of muscle involvement. On the sports performance in sprint kayak disciplines (200 meters and 500 meters) the strength parameters in bench pull on the horizontal bench are statistically important (Szanto, 1991, 2004; Šebesta \& Podlucký, 2002). The proportion of power in the bench press and bench power is balanced in the medium distance discipline (1000 meters). With the increasing length of kayak disciplines (5000 meters 
and 21500 meters), the proportion of strength parameters varies in favor of power in the bench pull (Sanders, 1998).

\section{Conclusion}

The used approach allowed pay attention to the strength parameters, which provide the essential information to an explanation of sports performance in kayak disciplines. It shows that in the sprint disciplines (200 meters and 500 meters) has a greater impact on the sports performance strength parameters measured in bench pull than in the bench press. In middle distance discipline (1000 meters) the share of power in bench press and bench pull is balanced. With the increasing length of kayak discipline (5000 meters and 21500 meters), the proportion of strength parameters varies in favor of power in the bench press. From the parameters of maximum power and power endurance in bench press and bench pull in all kayak disciplines the parameter of average power in power endurance was proved to explain sports performance. Knowledge of these factors will allow optimizing the content of sports training of kayakers, the process of developing their strength skills, and their transformation process into a structure of sports performance and kayaking paddling technique.

\section{Conflict of Interest}

The authors declare that there is no conflict of interest.

\section{References}

Akca, F., Muniruglu, S. (2008). Anthropometric - somatype and strength profiles and on - water performance in Turkish elite kayakers. Int J Appl Sport Sci, 20(1), 22-34.

Bielik, V., Dalcheco, L.H., Vajda, M., Lopata, P., Chudý, J., \& Manchado-Gobatto, F.B. (2019). Is the aerobic power a delimitating factor for performance on canoe slalom? An analysis of Olympic Slovak canoe slalom medalists and non-Olympics since Beijing 2008 to Rio 2016. J Hum Sport Exerc, 14(4), 876-892. https://doi.org/10.14198/jhse.2019.144.16

McKean, M., Burkett, B.J. (2014). The Influence of Upper Body Strength on Flat-Water Sprint Kayak Performance in Elite Athletes. Int J Sports Physiol Perform, 9(4), 707-14. https://doi.org/10.1123/ijspp.2013-0301

Plagenhoef, S. (1979). Biomechanical analysis of Olympic flatwater kayaking and canoeing. Res. Q. Exerc. Sport, 50(3), 443-459.

Schmidt, K.H. (1992). Techniktraining im Kanurennsport. Duisburg: Deutscher Kanu-Verband, 145.

Doktor, M. (2001). Paddle technique and strategy in speed canoe. [Diploma thesis] Praha: UK Praha.

Barton, G. (2002). Epic wing paddles. Retrieved 10. 3. 2004 from World Wide Web: http://www.epicpaddles.com

Baker, J., Rath, D., Sanders, R., Kelly, B. (1999). A threedimensional analysis of male and female elite sprint kayak paddlers. In R. Sanders \& B. Gibson (Ed.). Scientific Proceedings of the XVII. International Symposium on Biomechanics in Sports. (pp. 53-56). Perth, Edith Cowan University

Sendelbeck, K., Schmid, T. (2016). Paddeln lernen: Sicher und schnell in Kajak und Canadier - Einstieg in den KanuRennsport verständlich erklärt für Kinder, Jugendliche, Eltern und Betreuer. Duisburg: Deutscher Kanu-Verband, (pp. 144), ISBN-10: 3937743588
Lopata, P. (2014). Speed canoeing - A look at the structure of sports performance, physiological parameters and sports diagnostics. National Sport Center, Bratislava. Retrieved from http://www.sportcenter.sk/userfiles/file/Lopata_ rychlostna_kanoistika_2014.pdf

Kendal, S.J., Sanders, R.H. (1992). Technique of elite flatwater kayak paddlers using the wing paddle. Intl J Sport Biomech, 8(3), 233-250. https://doi.org/10.1123/ijsb.8.3.233

Stecenko, J.N., et al. (1982). General characteristics of the stroke cycle. In Kanoistika. Proceeding of specialized translations. Praha: Olympia, 21-39.

Vieira, A. N., Messias, L. D. H., Cardoso, V. M., Ferrari, G. H., Cunha, A. S., Terezani, R. D., Manchado-Gobatto, B. F. (2015). Characterization and reproducibility of canoe slalom simulated races: physiological, technical and performance analysis. J. Hum. Sport Exerc., 10(4), 835846. https://doi.org/10.14198/jhse.2015.104.01

Bauer, A., Hillmervogel, U., \& Kanzow, E. (1988). Influences of the preconditions of performance on the power-demand during white-water-canoeing. In International Journal of Sports Medicine, 9(5), 379-379).

Gagin, J.A. (1981). Basics of paddling technique. In: Canoeing. Proceedings of specialized translations. Praha: ÚV ČSTV, 13-19.

Borkovcová, Š. (2005). Dependence between the sports effect of race course and select index on conditional element in the flat water racing. [Diploma thesis]. Praha: UK FTVS.

Janura, M., Kratochvíl, J., Lehnert, M., Vaverka, F. (2005). An analysis of the forward stroke as used in a wild water kayak on flat waters. Acta Gymnica, 35(2), 113-117.

Grigorijev, J., Krasnopecev, G.M. (1972). Dynamika tempa grebli na bajdarakach i kanoe na različnych distancijach, Grebnoj sport. Moskva: FiS, 90-92.

Cohen, J. (1988). Statistical Power Analysis for the Behavioral Sciences. Routledge.

Endicott, W. (1995). The Barton Mold, a Study in Sprint Kayaking. A publication of the U.S. Canoe and Kayak Team, second edicion. Czech translation: Šebesta, P. - Podloucký, V. Speed canoeing and Greg Bartons'training system. Praha: ČSK, Olympia.

Potočný, V. (1985). Physical development as a prerequisite for sports performance in canoeing. In: Proceedings report from scientific conference Bratislava 1985, Praha: ÚV ČSTV, Department of Methodology of Science, 409-466.

Strnadová, M. (2004). Analysis of muscle chain engagement during forward kayaking in whitewater downhill. [Diploma thesis]. Praha: UK FTVS.

Bílý, M., Kračmar, B., Novotný, P. (2000). Canoeing. Praha: Karolinum.

Joachimsthaler, F. (1967). Study of the dependence between the strength of paddle stroke and the external form of movement during paddling. Proceedings of Scientific Council. ÚV CSTV, Praha: Olympia, 117-142.

Rodano, R., Squadrone, R., Sacchi, M., Marzegan, A. (2001). 3-D kinematic analysis of canoeing on simulator: differences between elite, intermediate and novice canoists. Biomechanics symposia 2001, San Francisco: University of San Francisco.

Janura, M., Kubu, P., Kratochvíl, J., Stromšík, P. (2000). Kinematic analysis of forward stroke at wild water kayak paddling. In F. Vaverka \& M. Janura (Ed.), Proceedings of the conference Biomechanics of Man 2000. Olomouc: Palacký University, 251-254.

Fučíková, K. (2003). Analysis of paddling technique in speed canoeing according to time division of stroke. [Diploma thesis] Praha: UK FTVS. 

and Barbell Bench Pull on a Horizontal Benchin Sports Performance in Kayak Disciplines

Szanto, C. (1991). Racing canoeing. Beijing, China: China Printing Corporation.

Szanto, C. (2004). Racing canoeing. 2nd edt. Argentina: Gráfica Vuelta de Página Ltda, 263.

Šebesta, P., Podloucký, V. (2002). Speed canoeing and Greg

Bartons'training system. Praha: Czech Canoe Union.
Sanders, R.H. (1998). Lifting performance in aquatic sports. Joondalup, Western Australia: Edith Cowan University, 1998. Retrieved http://www.isbs98.uni-konstanz.de/ fullpaper/FullRossSanders.pdf

\title{
ЧАСТКА СИЛОВИХ ПАРАМЕТРІВ ЖИМУ ЛЕЖАЧИ ТА ТЯГИ ШТАНГИ НА ГОРИЗОНТАЛЬНІЙ ЛАВІ У СПОРТИВНИХ ПОКАЗНИКАХ У ДИСЦИПЛІНАХ ВЕСЛУВАННЯ НА БАЙДАРКАХ
}

\author{
Ярослав Бродані ${ }^{1 \mathrm{ABCD}}$, Наталія Дворжачкова ${ }^{2 \mathrm{ABCD}}$, \\ Моніка Чакова ${ }^{3 \mathrm{ABCD}}$, Зденек Малік ${ }^{4 \mathrm{~B}}$, Петро Лопата ${ }^{5 \mathrm{~B}}$ \\ 1,2,3,4Університет Костянтина Філософа в Нітрі \\ ${ }^{5}$ Словацький національний спортивний центр \\ Авторський вклад: А - дизайн дослідження; В - збір даних; C - статаналіз; D - підготовка рукопису; Е - збір коштів \\ Реферат. Стаття: 6 с., 6 табл., 31 джерело.
}

Метою дослідження було розглянути співвідношення параметрів максимальної м'язової сили та силової витривалості та пояснити їхній внесок у спортивні показники у дисциплінах веслування на байдарках членів національної збірної Словаччини.

Матеріал і методи. Силові параметри контролювали за допомогою Tendo Power Analyzer у жимі штанги та тяги на горизонтальній лаві. Діагностична серія тестів максимальної потужності і ефективних повторень на силову витривалість була проведена як у вправах на жим штанги лежачи, так і у вправах на тягу лежачи. Для визначення факторів, що обмежують спортивні показники в дисциплінах веслування на байдарках 200 метрів, 500 метрів, 1000 метрів, 5000 метрів та марафоні 21500 метрів, використовували оцінку залежності між усіма силовими змінними. Для зменшення показників використовувалася покрокова регресія.

Результати. Було виявлено, що у дисциплінах спринтерського веслування на байдарках (200 метрів, 500 метрів) на спортивні показники впливає тяга штанги більше, ніж жим штанги на горизонтальній лаві. У дисциплінах на середні дистанції (1000 метрів) співвідношення параметрів сили виважене. Зі збільшенням довжини дисциплін у веслуванні на байдарках (5000 метрів та 21500 метрів) співвідношення параметрів сили змінилося на користь жиму штанги.

На основі параметрів максимальної м'язової продуктивності та м'язової витривалості, виміряних у жимі штанги та тязі на горизонтальній лаві, була використана середня потужність силової витривалості для пояснення спортивних результатів у дисциплінах веслування на байдарках.

Висновки. Аналіз показників максимальноїпотужності та силової витривалості в жимі лежачи та тязі лежачи доводить, що у всіх дисциплінах веслування на байдарках параметр середньої потужності в силовій витривалості пояснює спортивні результати. Знання цих чинників дозволить оптимізувати зміст спортивної підготовки байдарочників, процес розвитку їх силових здібностей та процес їх трансформації в структуру спортивної діяльності та техніку веслування на байдарках.

Ключові слова: спортивні показники, дисципліни веслування на байдарках, покрокова регресія, Національний спортивний центр

\section{Information about the authors:}

Brodáni Jaroslav: jbrodani@ukf.sk; http://orcid.org/0000-0002-0126-8514; Department of Physical Education and Sport, Faculty of Education, Constantine the Philosopher University in Nitra, Tr. A. Hlinku 1, 94901 Nitra, Slovak Republic.

Dvořáčková Natália: natalia.dvorackova@ukf.sk; http://orcid.org/0000-0001-8207-1299; Department of Physical Education and Sport, Faculty of Education, Constantine the Philosopher University in Nitra, Tr. A. Hlinku 1, 94901 Nitra, Slovak Republic. Czaková Monika: monika.czakova@ukf.sk; http://orcid.org/0000-0002-1594-1079; Department of Physical Education and Sport, Faculty of Education, Constantine the Philosopher University in Nitra, Tr. A. Hlinku 1, 94901 Nitra, Slovak Republic.

Malík Zdenek: zdenek.malik@student.ukf.sk; http://orcid.org/0000-0002-4085-0566; Department of Physical Education and Sport, Faculty of Education, Constantine the Philosopher University in Nitra, Tr. A. Hlinku 1, 94901 Nitra, Slovak Republic.

Lopata Peter: peter.lopata@sportcenter.sk http://orcid.org/0000-0001-6103-216X; Slovak National Sports Center, Trnavská cesta 39 (Športová hala Mladost'), 83104 Bratislava, Slovak Republic.

Cite this article as: Brodáni, J., Dvořáčková, N., Monika Czaková, M., Zdenek Malík, Z., \& Lopata, P. (2021). Share of Strength Parameters of Bench Press and Barbell Bench Pull on a Horizontal Benchin Sports Performance in Kayak Disciplines.Teorîa ta Metodika Fizičnogo Vihovannâ, 21(1), 90-95. https://doi.org/10.17309/tmfv.2021.1.12

Received: 23.02.2021. Accepted: 20.03.2021. Published: 25.03.2021

This work is licensed under a Creative Commons Attribution 4.0 International License (http://creativecommons.org/licenses/by/4.0). 